\title{
Erosion and sediment transport modelling to inform Payment for Ecosystem Services schemes
}

\author{
Barbara Benisiewicz • Andrea Momblanch • Alister \\ Leggatt • Ian P. Holman
}

Received: date / Accepted: date

\begin{abstract}
Erosion and the impacts of the redistribution of sediment are a serious threat to the quality of water resources. They cause losses and/or additional expenses in many areas, such as water treatment, biodiversity or fisheries. The implementation of catchment management measures, aimed at preventing the transfer of sediment to rivers, can be a costbeneficial way to address the problem. In order to select the measures and appropriate locations for erosion control the spatially distributed soil erosion and sediment delivery model WaTEM-SEDEM was used. The model was calibrated against total suspended solids data at the outlet of the Wey catchment, South-east
\end{abstract}

\section{B. Benisiewicz}

Cranfield Water Science Institute,

Cranfield University, Cranfield, UK

E-mail: benisiewicz.basia@gmail.com

A. Momblanch

Cranfield Water Science Institute,

Cranfield University, Cranfield, UK

I.P. Holman

Cranfield Water Science Institute,

Cranfield University, Cranfield, UK

A. Leggatt

Affinity Water, Hertfordshire, UK
England, yielding satisfactory results. Different scenarios of catchment management were modelled to reduce the amount of sediment transported to the river. Scenarios introducing 24 retention ponds, $50 \mathrm{~m}$ wide buffer strips and cover crops in areas with the largest erosion and sediment delivery were tested. The largest decrease in both sediment production and sediment export were obtained using cover crops, with reductions of $13.4 \%$ and $14.1 \%$, respectively. A cost-benefit analysis considering multiple ecosystem services (e.g. control of erosion rates, attenuation of mass flow, pest control, wildlife and its outputs) identified the cover crops as the most cost-beneficial measure and a possible funding scheme based on Payments for Ecosystem Services was developed as a way to enable its implementation.

Keywords Soil loss · Sediment export . WaTEM-SEDEM · Retention ponds · Buffer strips · Cover crops · Catchment management

\section{Introduction}

Erosion is a global problem identified in many different catchments, with a high risk of occurrence particularly in agricultural areas [1]. It is associated with the redistribution of sediment $[2,3,4]$, which often carries nutrients and con- 
taminants present in the catchment (e.g. phosphates, nitrates and pesticides) contributing to eutrophication and contamination of water courses [5]. Impaired water quality has a direct influence on freshwater ecosystems [2]. Moreover, it increases water treatment requirements and, thereby, associated costs [6]. The costs of removing nitrates and pesticides from surface waters to meet drinking water standards amounted to $£ 279$ million between 2008 and 2009 in the UK [7]. Erosion is also related to changes in soil structure and compaction that may cause a decrease in productivity of agricultural soils [8], which has been estimated in about $25 \%$ in the UK [2], and destruction of terrestrial habitats [9]. Acting in the catchment, i.e. at the source of the problem, by implementing solutions that prevent erosion and interrupt sediment transport can reduce multiple impacts simultaneously. However, those solutions may involve significant initial investment and/or annual costs and their efficacy is often uncertain, which might prevent them from being implemented in practice [10].

Although there is still significant uncertainty around the approach $[11,12]$, Payment for Ecosystem Services (PES) schemes have the potential to support catchment management policy and planning practice [13]. PES can enable and fund nature-based solutions through the identification of the multiple Ecosystem Services (ES) and their potential buyers (i.e. ES beneficiaries) and sellers (i.e. ES providers) [11,14, 13]. In the UK, PES schemes are considered to be a powerful way to implement catchment management measures, including water quality and flood risk management [15], with possibilities of bringing additional benefits. The Irwell Catchment near Manchester is a successful example of the PES implementation [16]. The environmental value of the Irwell catchment was improved due to the cooperation of businesses, environmental agencies, landowners and local authorities. The activities related to the PES implementation brought environmental, economic and social benefits, and primarily included providing flood protection func- tion, improving the visually unattractive area of the river and giving it a recreational function [16]. In the report by Centre for Local Economic Strategies and Wildlife Trust for Lancashire, Manchester and North Merseyside it was estimated that the PES activities aimed at giving the area around the river a more natural character influenced, among others, the increase in property prices in this area by $1-$ $19 \%$. However, current evidence of PES profitability is mostly based on pilot experiments and mapping of current Ecosystem Service (ES) delivery $[17,18]$, which have limited predictive capabilities to assess the effectiveness of diverse solutions.

Modelling tools are useful to design catchment management measures and assess their efficacy [19]. There are many models which can be used to spatially assess erosion and sediment transport, e.g. WaTEM - SEDEM [20], SWAT [21], InVEST [22] and RIOS [23]. Some have been applied with an ES approach to quantify the sediment retention service under different land use scenarios [19]. In this paper, we combine a modelling approach with an economic valuation of the ES provided by the planned actions to propose a PES scheme. Firstly, we apply WaTEM - SEDEM to identify the main sources of erosion and sediment delivery routes, and to design and test different catchment management scenarios to reduce erosion and sediment export. The outcomes are used to perform a cost-benefit analysis that accounts for the benefits of the solutions in terms of sediment retention and other ES and informs the proposal for a PES scheme which can cover the implementation costs. The approach is applied to the River Wey catchment in southeast England.

\section{Materials and Methods}

\subsection{Study area}

With a catchment area of $1007 \mathrm{~km}^{2}$, the River Wey is a tributary of the Thames River and 
one of the major rivers in the county of Surrey [24]. Within the catchment, there are both large towns and extensive arable fields, which can be significant sources of erosion and sediment, and occupy $23.5 \%$ and $16.1 \%$ of the catchment area respectively. The predominant land cover is woodland $(30.6 \%)$ and a significant percentage of the catchment is covered by grasslands $(27.2 \%)$. Some of the watercourses were used for navigation, watermills and are subject to flood protection and urbanisation and are, therefore, strongly modified [25]. There are also numerous lakes and ponds in the catchment [25].

Soils in the Wey catchment are predominantly sandy and clayey, with occasional chalk soils present [26]. The elevation ranges from $13 \mathrm{~m}$ to $290 \mathrm{~m}$ above sea level.

\subsection{WaTEM-SEDEM}

\subsubsection{Model structure}

WaTEM-SEDEM is a spatially distributed soil erosion and sediment delivery model [27]. The model is based on WaTEM (Water and Tillage Erosion Model) and SEDEM (Sediment Delivery Model) [20] and, as such, its principle of operation is based on three modules: water erosion, sediment transport and tillage erosion. The Water erosion module calculates soil losses based on RUSLE equation [28]. In the next module of the model, sediment transport and sedimentation are calculated. This is based on the sediment transport capacity of surface runoff (Tc), which determines the amount of sediment delivered to surface water, taking into account the deposition of sediment in the landscape and ponds during transport. The last module of the model calculates tillage erosion, by which soil is displaced to the bottom of the slopes under the influence of agricultural tools and machinery [4] and which is directly related to changes in slope. For detailed information about WaTEM-SEDEM refer to [20].

\subsubsection{Model inputs}

The basic input to the model are elevation and land cover maps. The former, enables the calculation of slope gradients and slope length and, in conjunction with other data as pond, RUSLE C-Factor, K-Factor and R-Factor maps the definition of sediment delivery paths to the river. The model does not account for sediment processes within water bodies and considers that all sediment entering a water body is discharged at the outlet. The model considers five types of land cover: rivers, road infrastructure and built-up areas, arable field parcels, forests and pastures. Land cover determines erosion as it is related to RUSLE crop factor (C-factor) and also affects the transport capacity (Tc) which influences sediment deposition. The $\mathrm{C}$ factor reflects the impact of land use and management. Manipulating these activities is the easiest way to reduce erosion, which is why it is the most important factor in terms of land use policies and decisions [29]. With the objective of representing the effects of arable land distribution, WaTEM-SEDEM requires a land cover map detailing individual agricultural plots (Figure 1) which allows calculating erosion in each arable parcel separately as well as including the effect of parcel boundaries on sediment transport connectivity. Additionally, a soil erodibility factor (K-factor) map and a rainfall erosivity factor ( $\mathrm{R}$-factor) map are used in the calculation of soil losses and a map of ponds in the study area are used for calculation of sediment deposition. The K-factor map allows to identify areas with significant sensitivity of soil to erosion [30], while the R-factor map describes the rainfall influence on sheet and rill erosion [31]. Table 1 summarises the data used and the original sources.

\subsubsection{Model outputs}

WaTEM-SEDEM generates three scales of outputs: total catchment values, spatial raster maps and results for discreet elements (i.e. river reaches and ponds). The main model outputs are spa- 


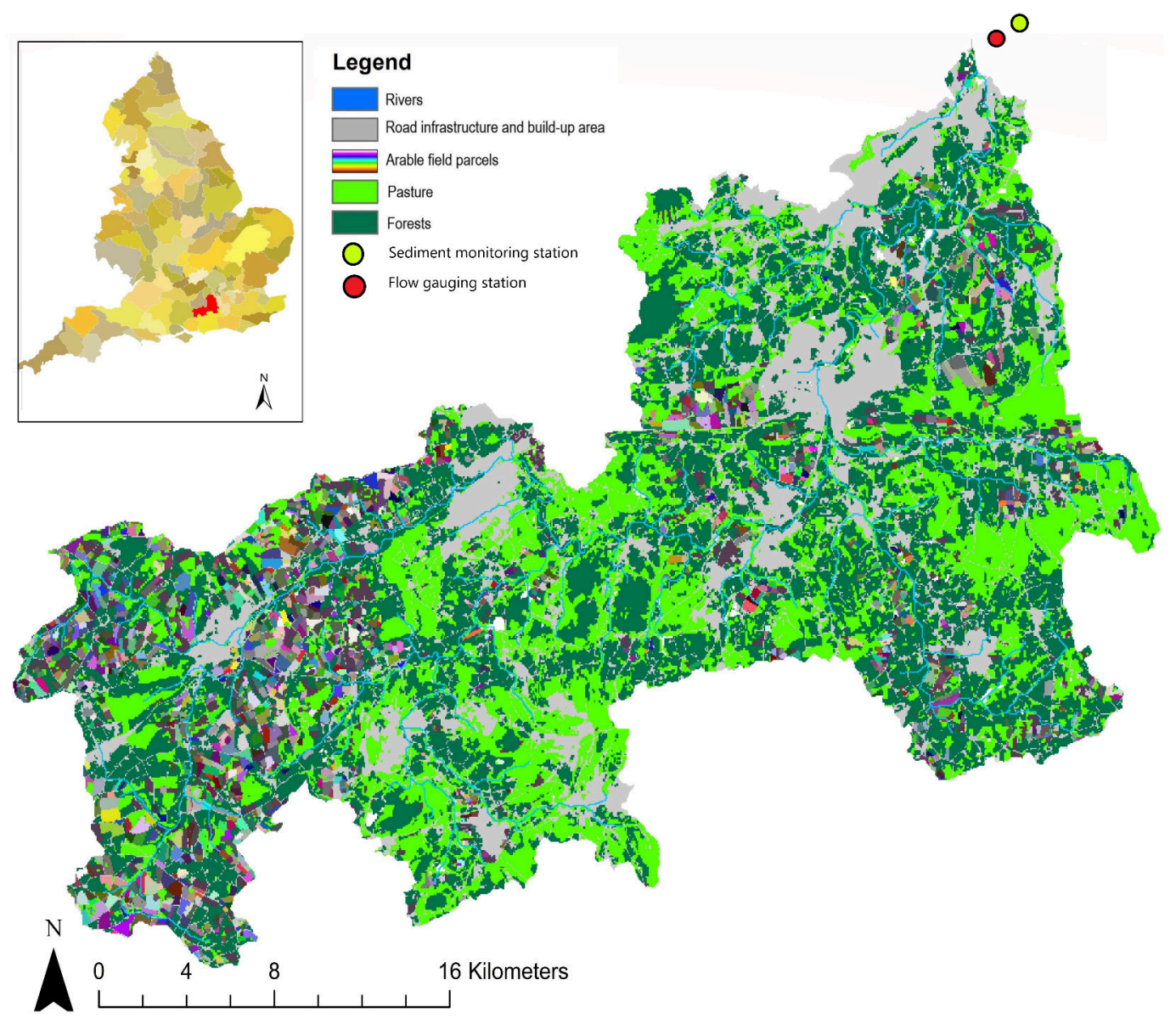

Fig. 1 Location of the Wey catchment in England, reclassified land cover map with individual arable field parcels, and flow and sediment monitoring stations.

Table 1 WaTEM-SEDEM input maps with information about scale, resolution, source and time reference.

\begin{tabular}{|l|l|l|l|l|}
\hline Map & Scale & Resolution & Source & Ref. time \\
\hline DEM & $1: 50000$ & $50 \mathrm{~m}$ & OS Terrain 50 DTM [32] & 2017 \\
Land cover & $1: 250000$ & $25 \mathrm{~m}$ & Land Cover Map 2015 [33] & 2015 \\
Roads & $1: 25000$ & - & OS Open Roads [32] & 2018 \\
Field parcels & Vector map & - & Rural Payment Agency [34] & 2010 \\
C factor & $1: 1000000$ & $100 \mathrm{~m}$ & ESDC [35] & 2010 \\
K factor & $1: 1000000$ & $500 \mathrm{~m}$ & ESDC [36] & 2010 \\
R factor & $1: 1000000$ & $500 \mathrm{~m}$ & ESDC [37] & $1970-2010$ \\
\hline
\end{tabular}

tial maps of annual average tillage erosion, water erosion and total erosion, and numeric annual average values of total sediment production (TSP), total sediment deposition (TSD), total sediment export (TSE) and total pond deposition (TPD) [20], where

$T S E=T S P-T S D-T P D$. 


\subsubsection{Model evaluation}

Discreet sampled (approximetly monthly) concentrations of total suspended solids at the outlet of the catchment were provided by the Environment Agency, while daily flows at a nearby gauging station were available from the National River Flow Archive [38] (Figure 1). Combining these data, a sediment rating curve was built to estimate daily suspended solid concentrations over time [39]. The annual average sediment load for the period $2007-2010$ was used for calibration in line with the reference time used for other model inputs (i.e. R-factor and C-factor: Table 1).

The parcel connectivity (to cropland and to forest / pasture), parcel trap efficiency (Ptef) for forest and pasture, maximum transport capacity coefficient $\left(k T c_{\max }\right)$ and minimum transport capacity coefficient $\left(k T c_{\min }\right)$ were manually adjusted to minimize the difference between the annual average observed sediment load $\left(t \cdot y^{-1}\right)$ at the catchment outlet obtained from the sediment rating curves and the total sediment export predicted by WaTEM-SEDEM $\left(t \cdot y^{-1}\right)$. An additional verification of the model was done by comparing the unit-area predicted model value of total sediment export with reported values for five English catchments [40, 41] with similar soil types, rainfall patterns and between $15-54 \%$ arable land; and the value of total sediment production with one identified catchment [41].

\subsection{Catchment management measures for sediment control}

A list of catchment management scenarios was prepared on the basis of identified actions directed to tackle water quality issues in the Countryside Stewardship agri-environment scheme [42]. The aim of the scenarios was to reduce the erosion (i.e. sediment production) and/or sediment transport. In line with the recommendations for the Wey catchment $[43,44]$ and the WaTEM-SEDEM capabilities, three measures were selected, i.e. sediment retention ponds, cover crops and grass buffer strips.

In the first scenario (Scenario 1), 24 retention ponds of $1 \mathrm{~m}$ depth were introduced to increase the deposition of sediment. On arable fields the ponds have an extent of 2 ha, while in urban areas they are 10 ha in agreement with other ponds and lakes identified in the catchment. The suitable location of the ponds was determined on the basis of the local Flood Risk Management Plan and the results of WaTEMSEDEM in relation to the areas with the highest sediment export. Scenario 2 introduces cover crops with the primary objective of decreasing erosion. As there is uncertainty about the effect of cover crops on the RUSLE cover factor, simulations were made assuming a reduction of $\mathrm{C}$ factor of $20 \%$ and $10 \%$ as in $[45,46]$. Since cover crops also reduce the amount of sediment that can be transported, the value of transport capacity $\left(k T c_{\max }\right)$ for arable lands was also changed based on [4]. Unlike the $\mathrm{C}$ factors which can be changed by pixel, $k T c_{\max }$ values are given for the whole catchment. This model constrain forced to consider the application of cover crops on all arable fields in the Wey catchment simultaneously. The third scenario (Scenario 3) introduced grass buffer strips around all arable field parcels (because they are the largest sources of sediments) bordering the river and its tributaries to increase sediment deposition. The width of the modelled buffer strips was equal to the model grid size $(50 \mathrm{~m})$.

\subsection{Cost-Benefit analysis and PES proposal}

The costs of implementing the scenarios were calculated based on the capital unit area or unit volume costs and maintenance/management costs for the three types of measures estimated for the UK [47], over a common period of 10 years (considered to be the lifespan of sediment retention ponds) [48]. To quantify the benefits of each scenarios, we first identified the range of ES that each measure could provide 
based on the Common International Classification of Ecosystem Services (CICES) (Table 2) [49]. Subsequently, the benefits were linked to the beneficiaries in the catchment and their capacity/willingness to pay was defined (binary yes/no variable) based on the type of agent/institution. The associated annual unit area or unit volume benefits were then calculated using different economic valuation techniques for ES. The avoided cost method was applied to estimate the 'Buffering and attenuation of sediment flows' using the average annual cost of sediment removal per volume of water treated, as provided by the local water company. The benefit transfer method was used to estimate other benefits using representative values by surface area provided by existing UK studies, which used valuation methods such as travel cost and contingent valuation [48], that could be easily extrapolated to the study area. The total benefit of each scenario was obtained by adding up the multiple benefits quantified. The summary of unitary costs and benefits is provided in (Table 2). Based on the equation

$$
N P V=\sum_{t=0}^{n} \frac{R_{t}}{(1+i)^{t}},
$$

where $N P V$ is the Net Present Value, $R_{t}$ is the net benefit for year $t$ obtained as the difference between the total benefits and the total capital (construction) and/or maintenance costs, $i$ is the discount rate $(5 \%)$ and $n$ is the number of years, a scenario with higher NPV has a larger margin between future returns and costs.

To design the PES scheme, we identified the ES providers as groups or agents in the catchment responsible for implementing the measure and the ES beneficiary as the ones receiving the benefits (Table 2). Based on this approach, if the NPV is greater than 1, it is assumed that the beneficiaries are willing to pay for the implementation of the proposed scenarios in exchange for the benefits they receive [5]. All costs related to the construction and maintenance of catchment management measures in each scenario are summarised in Ta- ble 2. As all scenarios are located entirely or partially in agricultural areas, the main group of ES providers would be farmers. In the case of ponds located in urban areas, ES providers would be local authorities, responsible for adapting local spatial development plans to the needs of the scenario, and developers. The ES beneficiaries group would mainly include water companies, environmental agencies and farmers which will benefit from all scenarios. In the case of ponds, beneficiaries would also include fishermen, citizens, as well as local businesses, for whom the ponds might create opportunities for recreation as well as provide some protection against floods. 


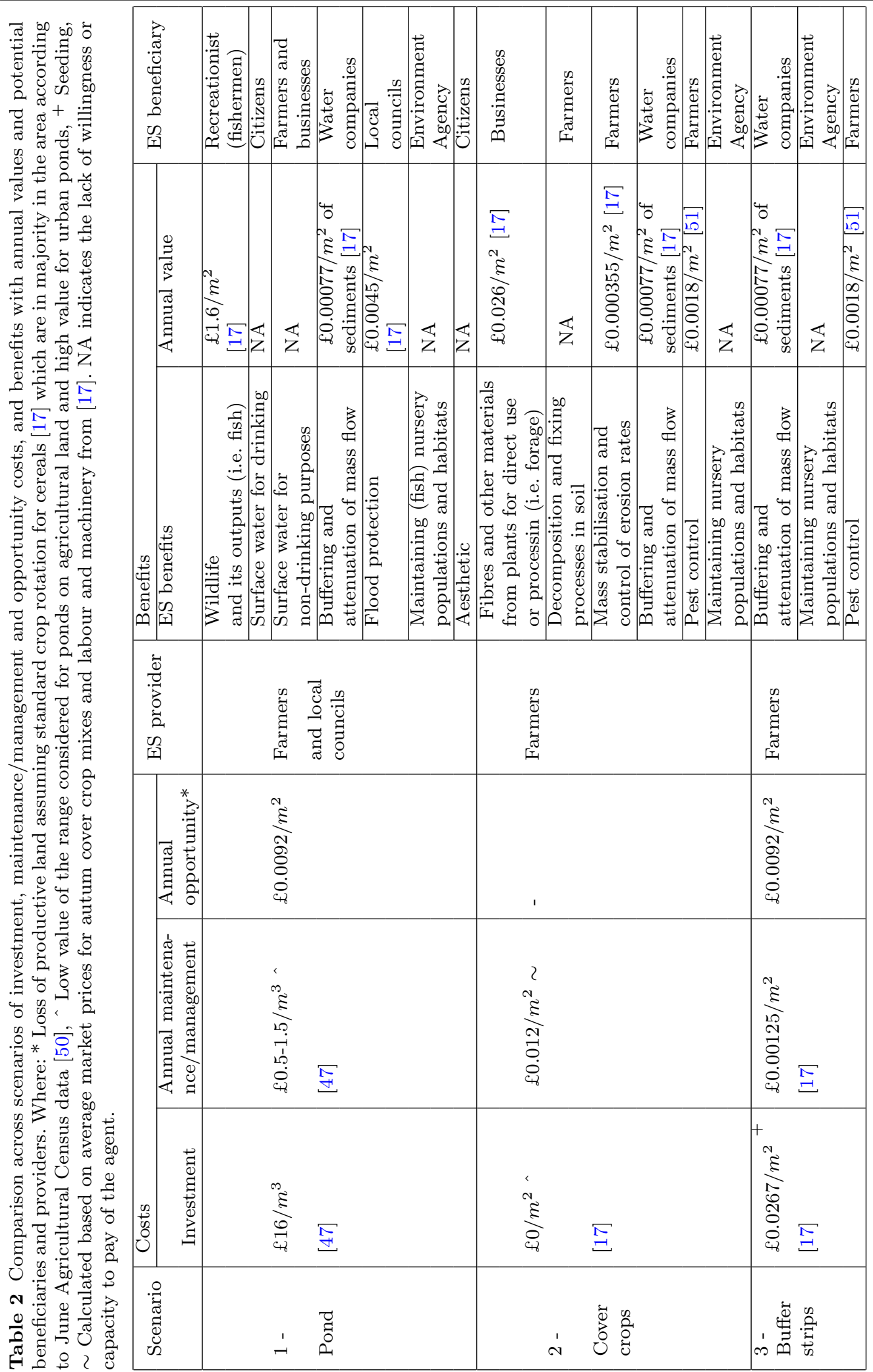




\section{Results}

\subsection{Model evaluation}

The calibration of model parameters in the ranges defined by previous studies (e.g., [52], [46]) provided a satisfactory model performance (Table 3). The resulting percent bias was $6.26 \%$ with respect to the observed sediment loads.

To further evaluate the model performance, Table 4 compares the unit area total sediment export provided by the model with reported values for the five catchments in UK . Data for these five catchments was available for the period 1971-1999. The total sediment export predicted by the model was smaller than the values for other catchments. However, given methodological and data uncertainties, these differences were considered not significant and the values represent the same order of magnitude. Total modelled sediment production values $\left(1.064 \mathrm{t} \cdot h a^{-1} \cdot y^{-1}\right)$ were also compared with those found in the Avon catchment, which were slightly higher $\left(1.300 \mathrm{t} \cdot h a^{-1} \cdot y^{-1}\right)$. Based on the performance evaluations, the model was considered as valid for scenario simulations.

\subsection{Results analysis}

\subsubsection{Baseline results}

Modelling made it possible to obtain information on the total sediment production and total sediment export for the catchment, the reduction of which was the main purpose of the catchment scenarios tested later. The average annual modelled total soil loss (i.e. total sediment production) for the catchment was 106, 440 t per year. The total average annual amount of sediment leaving the study area (i.e. total sediment export) was equal $7800 \mathrm{t}$ per year.

WaTEM-SEDEM results for the baseline allowed the identification of critical areas with the greatest intensity and extent of erosion and of sediment delivery routes. The greatest sediment production occurred in arable areas with the highest slopes, such as the western part of the Wey catchment (Figure 2). The main deposition areas can be observed along the tributaries of the river (Figure 2).

\subsubsection{Results of future scenarios}

The baseline results indicated the places with the greatest sediment production and transport (Figure 2, Figure 3). Using this output and taking into account slope, land use and recommendations described in Subsection 2.3, the location and extent of the measures were determined (Figure 3). Scenarios 1 and 3 focused on locations with the greatest sediment transport to capture the greatest amount of sediments possible. The 24 retention ponds had a total volume of $1,600,000 \mathrm{~m}^{3}$. Buffer strips had a total extension of 229 ha. Scenario 2 included cover crops in all arable fields, covering a total area of 14,066 ha.

As shown in Table 5, all the tested scenarios reduced both total sediment production and export. In Scenario 1, 24 retention ponds were introduced in urban and agricultural areas where the transport of sediment was the greatest. By locating the retention ponds between the sources of sediment and the river, larger amount of sediments were trapped which resulted in increased sediment deposition (TDP) and, thereby, reduced the amount of sediment leaving the study area (TSE). As some parts of agricultural parcels and urban areas were turned into ponds, in which soil loss is not possible, total sediment production decreased. The magnitude of change, however, is not significant due to the small size of the ponds in relation to the catchment area. Contrary to expectations, total sediment deposition dropped slightly. This can be explained by the fact that less sediments were produced, so fewer sediment was deposited on the ground along the path to the river.

The introduction of cover crops in Scenario 2 contributed to protect soil from rainfall and runoff impacts causing the total production of sediment to decrease both in the case of reducing $\mathrm{C}$ factor by $10 \%$ (Scenario $2 \mathrm{~A}$ ), and by 
Table 3 Parameters adjusted during calibration, their ranges and selected values for which the efficiency of the model is improved.

\begin{tabular}{|l|l|l|}
\hline Parameter & Parameter range & Calibrated value \\
\hline Parcel connectivity to cropland & $5-95$ & 60 \\
Parcel connectivity to forest/pasture & $5-95$ & 90 \\
Ptef: forest & $5-95$ & 75 \\
Ptef: pasture & $5-95$ & 75 \\
$k T c_{\min }$ & $5-200$ & 20 \\
$k T c_{\max }$ & $5-300$ & 50 \\
\hline
\end{tabular}

Table 4 Comparison of the values of total sediment export (TSE) predicted by WaTEM - SEDEM with five English catchments with similar characteristics. Data about total sediment production, data quality and sampling method for these catchment was obtained from Natural England Research Report [40]. Data about the percent of arable land, mean precipitation for period 1961-1990 and the predominant soil type were obtained from National River Flow Archive [38] .

\begin{tabular}{|l|l|l|l|l|l|}
\hline Catchment & $\begin{array}{l}\text { Arable land, } \\
\%\end{array}$ & $\begin{array}{l}\text { Precipitation, } \\
\mathrm{mm}\end{array}$ & $\begin{array}{l}\text { Predominant, } \\
\text { soil type }\end{array}$ & Method & $\begin{array}{l}\text { TSE, } \\
\mathrm{t} \cdot \mathrm{ha}^{-1} \cdot \mathrm{yr}^{-1}\end{array}$ \\
\hline River Wey & 23.5 & 825 & sandy, clay & Modelling & 0.08 \\
River Avon & 15.5 & 763 & sandy, peat & Rating curve & 0.27 \\
River Trent & 29.9 & 747 & clay, sand & Monitoring & 0.10 \\
River Exe & 20.0 & 1361 & sandy & Monitoring & 0.20 \\
River Piddle & 54.4 & 969 & sandy, gravel & Monitoring & 0.11 \\
River Rother & 22.4 & 811 & sandy & Monitoring & 0.14 \\
\hline
\end{tabular}

Table 5 Percentage scenario reductions in model outputs with respect to the baseline; where: TSP: Total Sediment Production, TSD: Total Sediment Deposition, TPD: Total Pond Deposition, TSE: Total Sediment Export. Negative percentages indicate a decrease in scenario values with respect to the baseline.

\begin{tabular}{|l|l|l|l|l|l|}
\hline & Baseline results & Scenario 1 & Scenario 2A & Scenario 2B & Scenario 3 \\
\hline TSP & 106440 & $-0.35 \%$ & $-9.69 \%$ & $-13.35 \%$ & $-0.79 \%$ \\
TSD & 81039 & $-0.09 \%$ & $-9.62 \%$ & $-13.71 \%$ & $2.21 \%$ \\
TPD & 17601 & $1.93 \%$ & $-9.19 \%$ & $-11.41 \%$ & $-9.56 \%$ \\
TSE & 7800 & $-8.29 \%$ & $-11.65 \%$ & $-14.08 \%$ & $-12.33 \%$ \\
\hline
\end{tabular}

$20 \%$ (Scenario 2B). Evidently, better results were achieved when $\mathrm{C}$ factor was reduced by $20 \%$, but they also reveal the non-linearity of erosion with respect to changes in $\mathrm{C}$ factor. The significant reduction in soil loss resulted in a decrease in the total sediment deposition, the total sediment exports and the total deposition of the pond.

In Scenario 3, $50 \mathrm{~m}$ wide strips of arable land bordering the river and its tributaries were transformed into grass buffer strips that have more capacity to protect the soil from rainfall erosion $[45,46]$, resulting in a reduction in total sediment production. However the main purpose of the buffer strips is to increase sediment deposition as they filter the runoff by intersecting the flow paths to the river. The reduced sediment production and their increased deposition resulted in a reduction of total sediment export and the total pond deposition.

For comparison with other scenarios we decided to take the conservative values of Scenario $2 \mathrm{~A}$. Figure 4 and Figure 5 show the differences in soil loss and sediment export in the catchment across scenarios.

\subsection{Cost-benefit analysis and PES}

All tested scenarios proved to be effective in the studied catchment, as they reduce total sediment export. However, an economic analysis is required to determine if they are cost- 


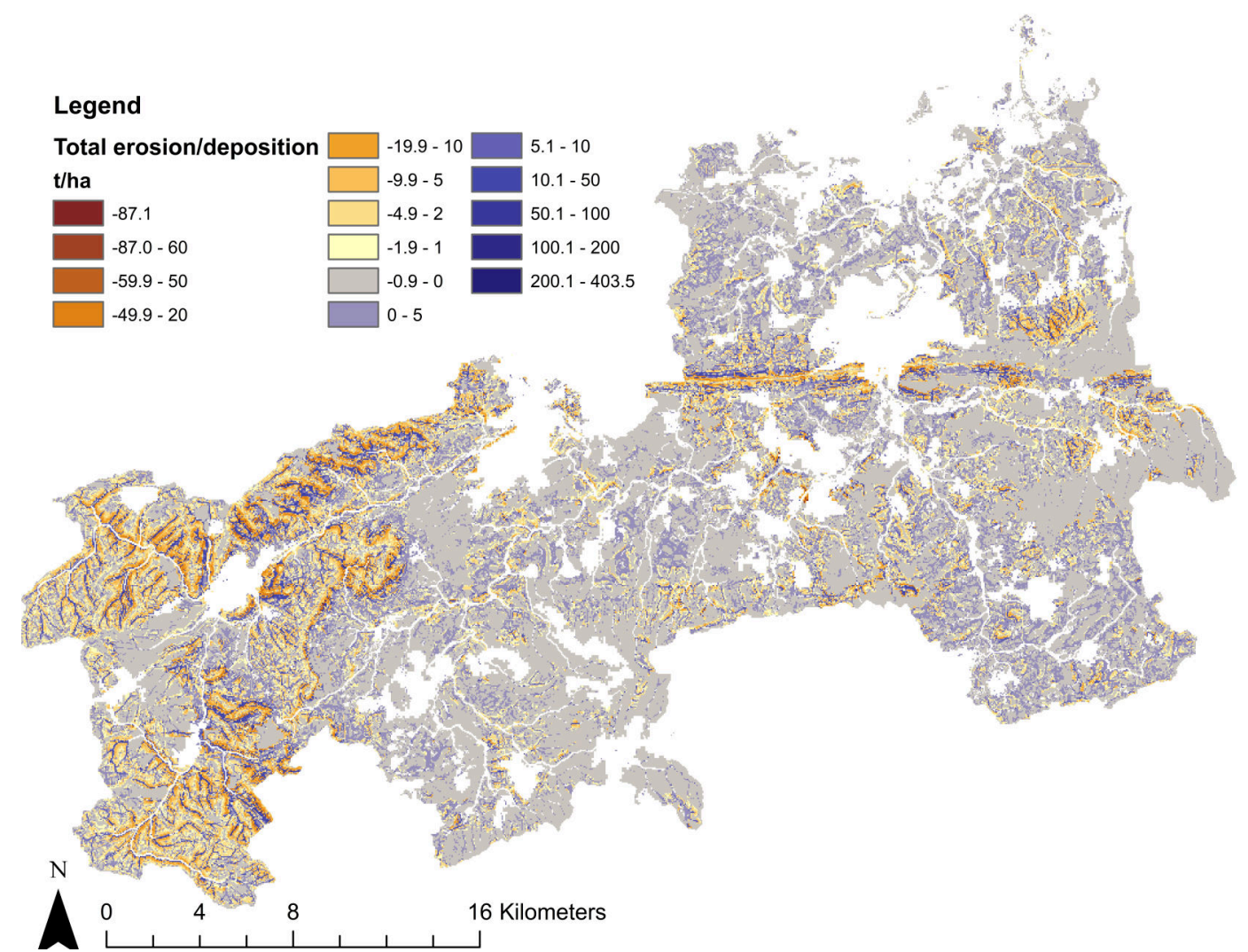

Fig. 2 Baseline average annual modelled erosion and sediment deposition $\left(\mathrm{t} \cdot \mathrm{ha}^{-1} \cdot \mathrm{yr}^{-1}\right)$. Negative values represent erosion, positive values represent sediment deposition, empty areas represent urban areas for which the model is not able to predict erosion and sediment deposition.

beneficial and, thereby, if they can be potentially funded under a PES scheme. To do so, the total investment and costs related to maintenance/management and the total ES-based benefits were calculated (Table 6) and the NPV was obtained for each scenario over a 10-year period with a $5 \%$ discount rate (Figure 6 ).

Figure 6 shows that the implementation of cover crops provides the greatest value of the investment (highest NPV) followed by buffer strips. The scenario considering ponds results in present costs that exceed the present value of the benefit revenues at the assumed discount rate $(5 \%)$ which would discourage ES providers to invest in that measure. This is due to the high investment costs and does not change significantly if lower discount rates are considered. According to these results, PES schemes could potentially be established to implement cover crops and buffer strips in the Wey catchment.

About $80 \%$ of the benefits brought by cover crops fall on businesses which can use them as productive factors such as forage and would, in principle, be willing to pay the farmers for the market product. The local water company abstracting water from the Wey River benefits from a reduction in the treatment costs due to lower sediment loads which represents $36 \%$ of the total benefits. Farmers implementing the cover crops also perceive benefits in relation to reduced soil loss, improved soil structure and natural pest control. Even though PES schemes require negotiation between the involved ES beneficiaries and providers, a scheme in which businesses and the local water com- 


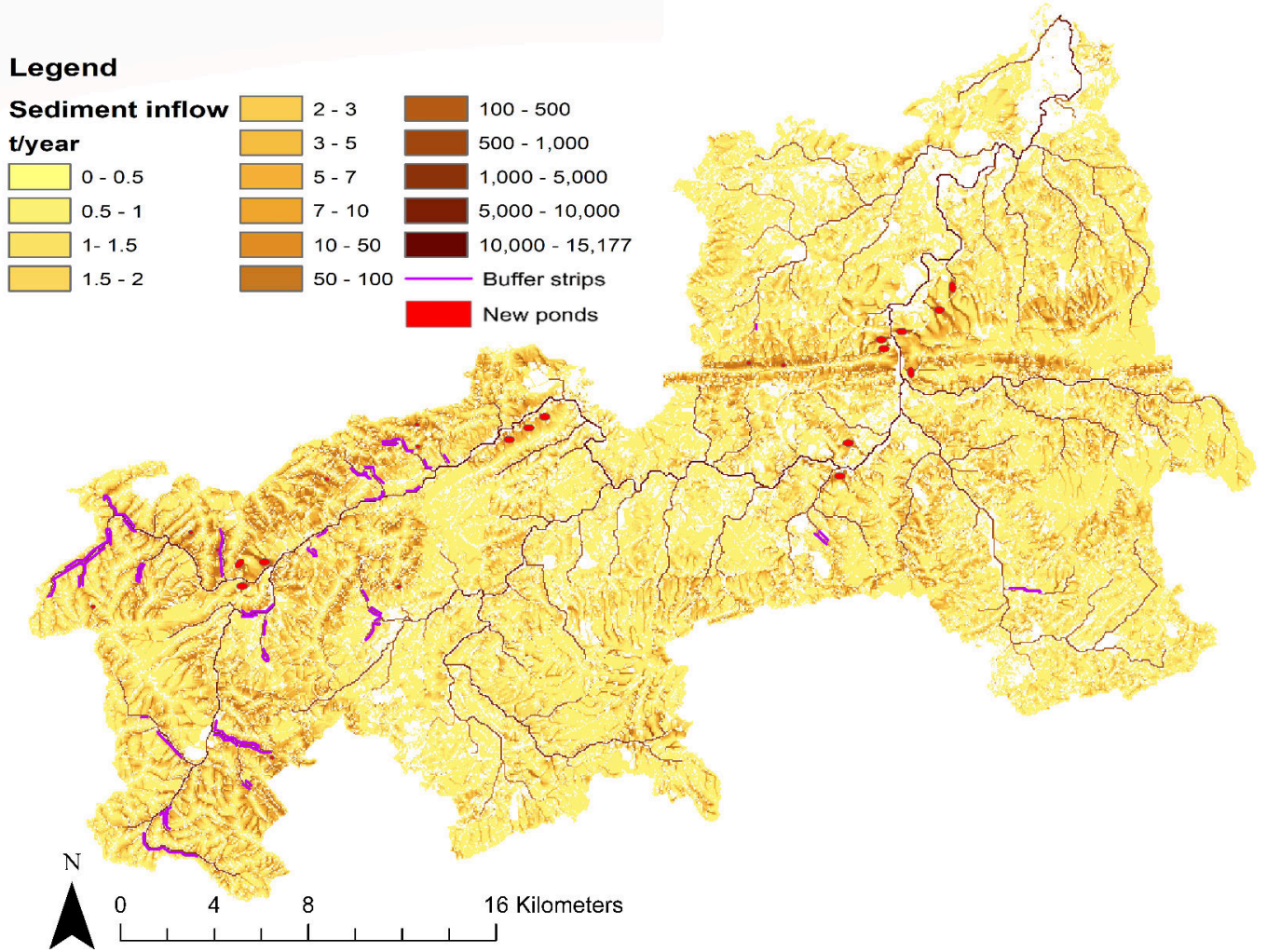

Fig. 3 Map of baseline average annual sediment transport with the location of introduced retention ponds and grass buffer strips in the Wey catchment.

Table 6 Summary of the total costs and benefits of tested scenarios for a 10-year lifespan

\begin{tabular}{|c|c|c|c|c|}
\hline \multirow{2}{*}{ Scenario } & \multicolumn{2}{|l|}{ ES provider } & \multicolumn{2}{|l|}{ ES beneficiary } \\
\hline & Agent & Cost & Agent & Benefit \\
\hline \multirow[t]{3}{*}{1 - Ponds } & Farmers & $\begin{array}{l}£ 3.2 \mathrm{mln} \\
+£ 0.102 \mathrm{mln} / \text { year }\end{array}$ & $\begin{array}{l}\text { Recreationist } \\
\text { (fishermen) }\end{array}$ & $£ 1.12 \mathrm{mln} /$ year \\
\hline & \multirow{2}{*}{ Local councils } & \multirow{2}{*}{$\begin{array}{l}£ 22.4 \mathrm{mln} \\
+£ 2.1 \mathrm{mln} / \text { year }\end{array}$} & Water companies & $£ 1.49 \mathrm{mln} /$ year \\
\hline & & & Local councils & $£ 0.007 \mathrm{mln} /$ year \\
\hline \multirow{3}{*}{2 - Cover crops A } & \multirow{3}{*}{ Farmers } & \multirow{3}{*}{$£ 1.69 \mathrm{mln} /$ year } & Businesses & $£ 3.66 \mathrm{mln} /$ year \\
\hline & & & Farmers & $£ 0.303 \mathrm{mln} /$ year \\
\hline & & & Water companies & $£ 0.70 \mathrm{mln} /$ year \\
\hline \multirow{2}{*}{3 - Buffer strips } & \multirow{2}{*}{ Farmers } & \multirow{2}{*}{$\begin{array}{l}£ 0.061 \mathrm{mln} / \text { year } \\
+£ 0.024 \mathrm{mln} / \text { year }\end{array}$} & Farmers & $£ 0.004 \mathrm{mln} /$ year \\
\hline & & & Water companies & $£ 0.74 \mathrm{mln} /$ year \\
\hline
\end{tabular}

pany cover $80 \%$ and $20 \%$ of the costs respectively, would provide net benefits to all parties (Figure 7). The fact that farmers do not have to contribute economically to implement the measure, would compensate them for the additional labour that sowing and harvesting the cover crops implies. In scenario 3, almost $100 \%$ of the benefit goes to the water company in terms of water treatment costs reduction. The investment and annual costs are much lower than the annual benefit to the water company. While the benefits to the farmers are minor and do not even cover the opportunity cost of lost productive land. Therefore, the water company could cover all costs in this case as it would recover the investment on the first year and would only reduce its benefits by $1 \%$. 


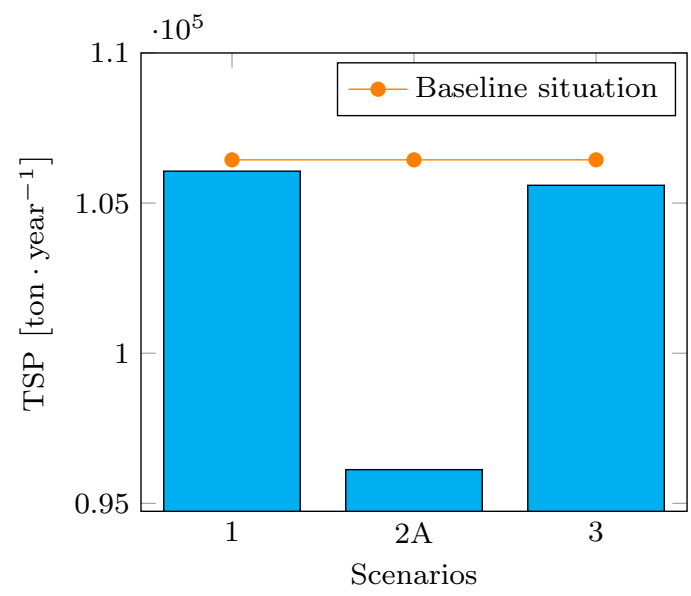

Fig. 4 Comparison of scenario effectiveness in reducing average annual total sediment production (TSP).

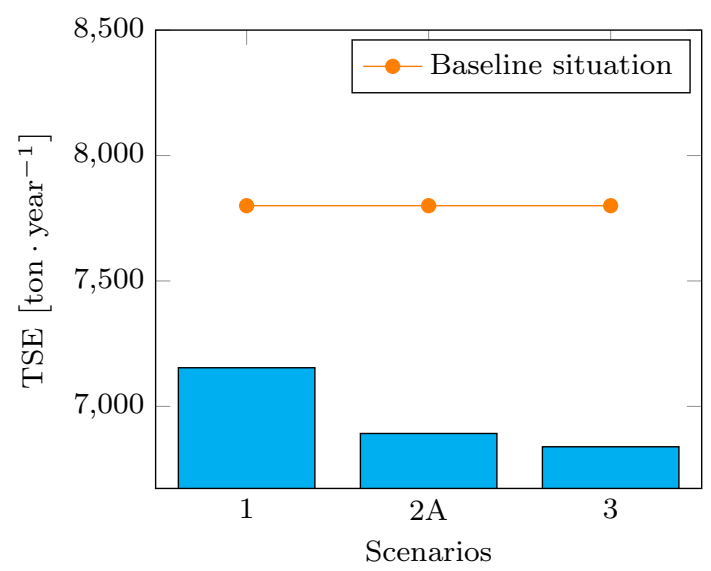

Fig. 5 Comparison of scenario effectiveness in reducing average annual total sediment export (TSE).

\section{Discussion}

The aim of this study was to propose a PES scheme for erosion and sediment delivery catchment management measures in the Wey catchment with the support of the spatially distributed soil erosion and sediment delivery model WaTEM-SEDEM. Results showed that the model allows the identification of the main sources of the problem as well as designing and testing the effectiveness of nature-based measures like cover crops, retention ponds and buffer strips. Cost and ES benefits related to each

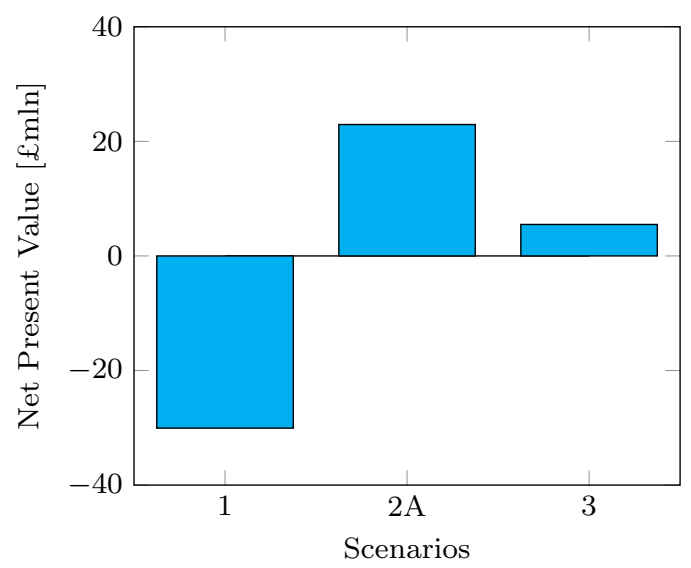

Fig. 6 Comparison of scenario Net Present Values (NPV).

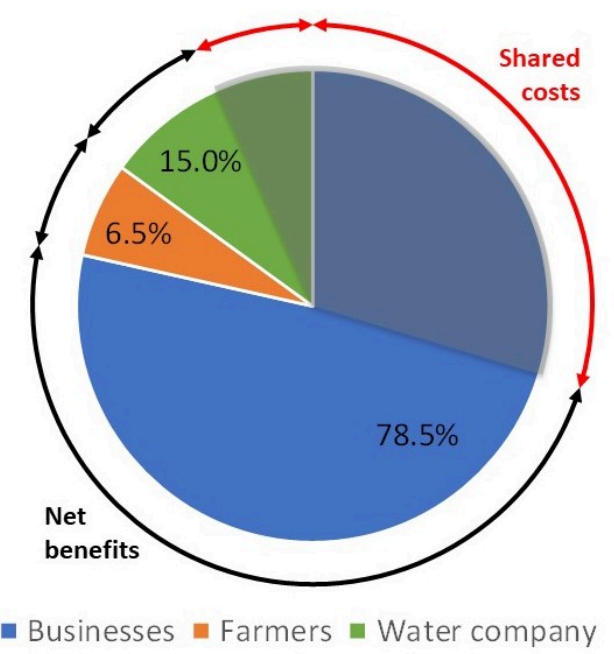

Fig. 7 Benefits, costs and net benefits distribution for scenario $2 \mathrm{~A}$.

measure were obtained using additional data from other studies in the UK and analysed from a PES perspective to identify potential ES beneficiaries and providers whose collaboration can make the implementation of the catchment management measures possible.

Modelling results show that the greatest total sediment production and export in the Wey catchment is on the western part of the catchment, due to the presence of most of the arable land. The values of both total sediment production and total sediment export provided by 
the model are slightly lower than those found for the catchments with similar characteristics. Not without significance is the fact that the catchments used for comparison are in varying degrees covered by arable land, which are the main source of sediment. However, a greater share of arable lands does not always translate into a higher value of total sediment export. Other important features of the catchment such as soil type, slope and the agricultural practices themselves are also significant.

Each tested scenario fulfilled its function and allowed for the reduction of both the total sediment export (TSE) and the total sediment production (TSP). The most effective method that allowed for the largest reduction in TSE and TSP is the extensive application of cover crops. This method allows for an annual reduction of the TSE by $14.1 \%$ and TSP by $13.3 \%$. [51] used the FARMSCOPER model to predict the effectiveness of cover crops in reducing sediment. For broadly defined crops, they predicted a wide range $(1.5-78.6 \%)$ of potential reduction in TSE [51]. In a report for England and Wales, [53] specified the effectiveness of cover crops in reducing TSE to be within the range of $20-80 \%$. The values obtained in the current study with WaTEM-SEDEM $(11.6 \%$ for $\mathrm{C}$ factor reduced in $10 \%$ and $14.1 \%$ for $\mathrm{C}$ factor reduced by 20\%) are slightly below the lower limits of the specified reduction ranges. This can be explained by the fact that the ranges in [53] were obtained on isolated linear slopes, which may not be representative at the larger catchment scale [45]. [54] and [46] report that the effectiveness of various catchment management measures in the reduction of TSE decrease in efficiency as the catchment area increased.

Grass buffer strips provided an annual reduction of TSE by $12.32 \%$ and TSP just by $0.79 \%$. [45] tested the effectiveness of $20 \mathrm{~m}$ wide grass buffer strips for three Belgian catchments of 2317 ha, 1718 ha and 1117 ha, with an average slope of $8 \%$. As the differences in the efficiency of buffer strips wider than $20 \mathrm{~m}$ are insignificant [54], described $20 \mathrm{~m}$ buffer strips can be compared to those $50 \mathrm{~m}$ wide tested in the model. In the case of Belgian catchments the total area covered by buffer strips was 35 ha and they were located along all rivers. In the case of the Wey catchment, the area occupied by the buffer strips was larger (229 ha), however, it is associated with a larger width of buffer strips. The differences between the total sediment export reduction for these catchments are not large, i.e. $19 \%$ for the Belgian catchments and $12.3 \%$ for Wey catchment. The reason for this difference, as in the case of ponds, can be found in a slightly different climate, land cover and the size of the catchment. Since both values represent a similar order of magnitude, the scenario results can be considered realistic.

The smallest reductions were obtained using retention ponds, which reduced annual TSE by $8.3 \%$ and TSP by $0.35 \%$. [45] tested the effectiveness of retention ponds in removing sediment on Belgian sub-catchments described above. In the case of such a small catchment, six introduced retention ponds reduced TSE by $19 \%$.

Analysing the aforementioned scenarios over a 10-year period, with the exception of retention ponds, the remaining scenarios are costbeneficial. The most cost-beneficial scenario is cover crops. In this scenario benefits are almost 4.5 times higher than costs in the 10 year period. Benefits are also 3.4 times higher than costs (in 10 years period) for the buffer strips. [55] made a similar estimation of costbenefit for $24 \mathrm{~m}$ wide grass buffer strips. While in the first year of implementation of this solution, additional costs amounted to $4583 €$, in the following years the estimate benefit was $34,000 €$ per year [56]. These values were mostly obtained relying on the benefit transfer method, which provides a fair indication of the possible costs and benefits that could be expected. It allows identifying the main winners and losers in the different catchment management scenarios and setting the basis for negotiations between ES beneficiaries and providers. However, it introduces additional uncertainty due to dif- 
ferences between the source and the application case studies [57], and, thus, the practical implementation of a PES scheme requires adhoc economic valuation studies for the specific catchment. Another source of uncertainty, is the volatility of prices of marketable ES, which in this study only include harvested cover crops sold as forage. This is an issue that has been analysed for other applications of agricultural residues such as bio-fuel production, with different solutions having been identified, e.g. promoting actors coordination and participation [58] and establishing large supply regions based on average yield density and under a fix price [59]. Finally, it should also be noted that only some of the numerous benefits associated with the modelled scenarios could be valued, so in reality the potential benefits may be greater. A better estimate of the potential benefits could be obtained by integrating a larger number of models, e.g. models to assess the effectiveness of flood protection.

As part of the PES scheme in scenario 3, the water company that bears the greatest benefits could cover the costs of their implementation and the maintenance costs. Reducing pollutions at the source through PES is becoming an increasingly favourable investment to water companies. Such solutions have a chance to significantly reduce the costs of subsequent water purification and help them comply with legislative requirements (e.g. the Drinking Water and Water Framework Directives). Moreover, nature-based solutions to improve water quality are an alternative to water treatment solutions, which will become increasingly inviable due to the commitment of water companies to be carbon neutral by 2030 [60]. In the UK, Water industry regulators, Ofwat and the Environment Agency are also increasing their expectation on water companies to realise wider ES benefits from their investments. As we have demonstrated in this study, incentivising cover crops through a PES mechanism has the potential to realise a wide range of additional benefits beyond just improvements in water quality. Affinity Water is an example of a water company, which have been implementing reverse auction catchment trading schemes focused on cover crops mostly focused in the reduction of nitrate leaching. Another example is South West Water which is implementing nature-based solutions by farmers to reduce pesticide pollution in surface water and is mainly financed under a PES program [61].

In most situations, PES schemes will build on the trust developed from pre-existing advisory schemes delivered by water companyemployed catchment advisors. New farmers can be included through spatial targeting and reverse auctions. Setting up a PES scheme involves an additional effort from water companies and the return on investments can take significantly longer than water treatment. However, incorporating and accounting for the wider benefits of PES schemes as part of a Natural Capital accounting process can make the return on such investments more favourable leading to a greater willingness to pay.

Other sectors that benefit from the implementation of cover crops may contribute to funding to a certain extent. For example, specific businesses could buy the harvested cover crops to use them as raw materials in their production processes. Cattle production (beef and dairying) is significant in the area and there are successful examples around the world that demonstrate the usefulness of cover crops as forage, especially in the US and Canada [62,61, 63]. According to the cost-benefit analysis, the average market value of forage is $£ 0.026 / \mathrm{m}^{2}$ (Table 2 ) but, as part of the proposed PES, businesses would pay less than $£ 0.01 / \mathrm{m}^{2}$ (calculated as $80 \%$ of the costs of implementing cover crops to farmers divided by the cultivated area). We believe that these prices, much below commercial prices, would encourage the participation of businesses in the PES. Therefore, with a detailed study of local businesses and their willingness to pay, as well as engagement activities, the implementation of the proposed PES is plausible.

In the case of ponds as a sediment retention measure, there is a wide group of potential 
beneficiaries, whose participation could help in the implementation of the scenario. If scenario 1 had resulted in a higher NPV, fishermen could benefit from the introduction of ponds for recreational purpses and, thereby, part of the fishing licenses in registered in the area could be devoted to pond maintenance. A similar method of financing takes place in the case of PES related to the protection of peatland habitats in the UK [64]. Most of the costs are covered by environmental organizations, but peatland visitors also contribute to habitat conservation, donating 2 each time they visit. Beneficiaries of the planned PES are also environmental charities, which are interested in creating new habitats and increasing biodiversity. Although the capacity of these organisations to cover the implementation costs of the proposed measures is limited, they could help raise funds through residents and stakeholders.

As recurrently highlighted in the discussion, the successful implementation of any PES requires investment of time and resources to build trust and capacities of stakeholders and their buy-in $[65,66]$. Detailed studies of local businesses and their willingness to pay, as well as engagement activities, accompanied with adhoc economic valuations are vital to establish fair and sustainable PES. The spatial explicit modelling work presented in this study provides the evidence to justify the investment of the PES set-up resources and represent a valuable tool along the different stages of the process.

\section{Conclusion}

The present study has shown how the application of the WaTEM-SEDEM model can be helpful for decision makers in planning the type and location of catchment management measures. On the basis of the modelling results, the arable field parcels with the largest production of sediment can also be identified and special attention can be focused on them when planning catchment management measures. The results from the model can be used as supporting evidence of scenario effectiveness in negotiations with farmers regarding the introduction of scenarios on their fields.

The present study shows how the combined use of modelling tools and cost-ES benefit analysis can support the development of Payment for Ecosystem Services schemes which can be the basis for implementation of nature-based catchment management solutions.

Acknowledgements The authors thanks Affinity Water for supporting this research and the Environment Agency for the provision of sediment sampling data, which enabled this article to be implemented.

\section{References}

1. G.P. Green, W.D. Heffernan, Journal of Rural Studies 3(2), 151 (1987)

2. P.N. Owens, A.J. Collins, Soil erosion and sediment redistribution in river catchments: measurement, modelling and management (CABI, 2006)

3. J. Boardman, Agriculture 3(3), 418 (2013)

4. L. Quijano, S. Beguería, L. Gaspar, A. Navas, Catena 138, 38 (2016)

5. C. Nduhiu, J.M. Gathenya, J.K. Mwangi, M. Aman, T. Mutisya, European Geosciences Union (2016)

6. C.g. Lee, T.D. Fletcher, G. Sun, Engineering in Life Sciences 9(1), 11 (2009)

7. S. Rolls, T. Sutherland, Bristol: Natural England (Natural England Research Reports, 057) (2014)

8. K. Van Oost, G. Govers, P. Desmet, Landscape ecology 15(6), 577 (2000)

9. Natural Capital Committee, Advice on soil management. Tech. rep., UK Government (2019)

10. D. Pimentel, L. Lach, R. Zuniga, D. Morrison, BioScience 50(1), 53 (2000)

11. S.S. Sayre, Environmental and Resource Economics pp. 1-35 (2018)

12. L.S. de Lima, T. Krueger, J. García-Marquez, Ecosystem services 27, 139 (2017)

13. J. Hack, Water International 40(5-6), 929 (2015)

14. L. Smith, A. Inman, R. Cherrington, Environmental science \& policy 24, 92 (2012)

15. Department for Environment, Food and Rural Affairs, Developing the potential for payments for ecosystem services: an action plan. Tech. rep., UK Government (2013) 
16. Centre for Local Economic Strategies and Wildlife Trust for Lancashire, Manchester and North Merseyside, Payment for Ecosystem Services Irwell Catchment. Tech. rep., UK Government (2015)

17. H. Posthumus, L. Deeks, R. Rickson, J. Quinton, Soil use and management 31, 16 (2015)

18. J. Nix, et al., The John Nix farm management pocketbook. Ed. 39 (The Andersons Centre, 2008)

19. A. Lüke, J. Hack, Sustainability 10(2), 346 (2018)

20. B. Notebaert, B. Vaes, G. Verstraeten, G. Govers, WaTEM-SEDEM version 2006 Manual. K.U. Leuven, Physical and Regional Geography Research Group (2006)

21. U.A.R.S. (ARS). Soil and water assessment tool. https://swat.tamu.edu/ (2019)

22. S. University. Integrated valuation of ecosystem services (invest). https: //naturalcapitalproject.stanford.edu/ invest/ (2019)

23. S. University. Rios: Resource investment optimization system. https: //naturalcapitalproject.stanford.edu/ software/ (2019)

24. APEM, Remote sensing for catchment management; lower wey investigation. apem scientific report 414265. Tech. rep., Thames Water (2015)

25. J. Jones, River Wey Catchment Vision. Consultation Draft. Tech. rep., Wey Landscape Partnetship (2014)

26. Land Information System. Landis map viewer. http://www. landis.org.uk/mapviewer/ (2018). Accessed: 2018-05-25

27. G. Verstraeten, I.P. Prosser, Geomorphology 98(3-4), 199 (2008)

28. K.G. Renard, G.R. Foster, G.A. Weesies, J.P. Porter, Journal of soil and Water Conservation 46(1), 30 (1991)

29. P. Panagos, P. Borrelli, K. Meusburger, C. Alewell, E. Lugato, L. Montanarella, Land use policy 48, 38 (2015)

30. P. Panagos, K. Meusburger, C. Ballabio, P. Borrelli, C. Alewell, Science of the total environment 479, 189 (2014)

31. P. Panagos, C. Ballabio, P. Borrelli, K. Meusburger, A. Klik, S. Rousseva, M.P. Tadić, S. Michaelides, M. Hrabalíková, P. Olsen, et al., Science of the Total Environment 511, 801 (2015)

32. The University of Edinburgh. Digimap. https://digimap.edina.ac.uk/os (2018). Accessed: 2018-06-23

33. The University of Edinburgh. Digimap. https://digimap.edina.ac.uk/environment (2018). Accessed: 2018-06-23
34. Pear Technology. Free rural payment agency maps for digital mapping. https://www.peartechnology.co.uk/free-ruralpayment-agency-maps/ (2018). Accessed: 2018-06-23

35. European Soil Data Centre (ESDAC). Cover management factor (c-factor) for the eu. https://esdac.jrc.ec.europa.eu/content/covermanagement-factor-c-factor-eu (2018). Accessed: 2018-06-23

36. European Soil Data Centre (ESDAC). (soil erosion by water (rusle2015). https://esdac.jrc.ec.europa.eu/content/soilerosion-water-rusle2015 (2018). Accessed: 2018-06-23

37. European Soil Data Centre (ESDAC). (global rainfall erosivity). https://esdac.jrc.ec.europa.eu/content/globalrainfall-erosivity (2018). Accessed: 2018-06-23

38. National River Flow Archive. Wey at guildford. http://nrfa.ceh.ac.uk/data/station/ meanflow/39141 (2018). Accessed: 2018-05-25

39. K. Vercruysse, R.C. Grabowski, R. Rickson, Earth-Science Reviews 166, 38 (2017)

40. C. Mainstone, Investigations into the use of critical sediment yields for assessing and managing fine sediment inputs into freshwater ecosystems. Tech. rep., Natural England (2008)

41. W. Dickinson, Occurrence and control of soil erosion and fluvial sedimentation in selected basins of the Thames river watershed. Tech. rep., Stratford-Avon River Environmental Management Project (1982)

42. Rural Payments Agency, Department for Environment, Food and Rural Affairs, Forestry Commission, Natural England, Countryside stewardship: Mid tier and new cs offers for wildlife manual. Tech. rep., UK Government (2018)

43. Environment Agency, Thames river basin district flood risk management plan 2015- 2021. Tech. rep., UK Government (2016)

44. S. Malaure, Catchment implementation plan: Wey catchment. Tech. rep., Surrey Wildlife Trust (2012)

45. G. Verstraeten, K. Oost, A. Rompaey, J. Poesen, G. Govers, Soil Use and Management 18(4), 386 (2002)

46. A. Van Rompaey, J. Krasa, T. Dostal, G. Govers, in The Interactions between Sediments and Water (Springer, 2003), pp. 169-176

47. K. Keating, H. Keeble, A. Pettit, D. Stark, Delivering benefits through evidence. cost estimation for suds - summary of evidence. Tech. rep., Environment Agency (2015)

48. Department for Environment, Food and Rural Affairs, Payments for ecosystem services: A best practice guide. Tech. rep., UK Government (2013) 
49. R. Haines-Young, M. Potschin, Common international classification of ecosystem services (cices): consultation on version 4, augustdecember 2012. Tech. rep., European Environment Agency (2013)

50. The University of Edinburgh. Digimap. https://digimap.edina.ac.uk/ (2018). Accessed: 2018-06-23

51. A.L. Collins, Y. Zhang, P. Naden, Proceedings of the International Association of Hydrological Sciences 367, 382 (2015)

52. N. Bezak, S. Rusjan, S. Petan, J. Sodnik, M. Mikoš, Environmental Earth Sciences 74(6), 5245 (2015)

53. H. Balshaw, P. Newell, N. Critchley, D. Harris, S. Twining, B. Chambers, Post harvest management for soil degradationreduction in agricultural soils: methods, occurrence, cost and benefits. Tech. rep., ADAS (2013)

54. G. Verstraeten, J. Poesen, K. Gillijns, G. Govers, Hydrological Processes: An International Journal 20(20), 4259 (2006)

55. J. Morschel, D. Fox, J.F. Bruno, Environmental Science \& Policy 7(1), 39 (2004)

56. J. Morschel, D. Fox, J.F. Bruno, Environmental Science \& Policy 7(1), 39 (2004)

57. A. Momblanch, J.D. Connor, N.D. Crossman, J. Paredes-Arquiola, J. Andreu, Journal of Hydrology 538, 293 (2016)

58. A. Mertens, J. Van Meensel, L. Willem, L. Lauwers, J. Buysse, Biomass and bioenergy 109, 209 (2018)

59. R. Golecha, J. Gan, Renewable and Sustainable Energy Reviews 57, 34 (2016)

60. W.U.C. Affairs. Water industry takes significant first step in drive to be carbon zero. https://www.water.org.uk (2019)

61. A. Omokanye, H. Lardner, L. Sreekumar, L. Jeffrey, Journal of Applied Animal Research 47(1), 303 (2019)

62. R. Stockwell, E. Bitan, National Wildlife Federation (2011)

63. J. Debes, No-Till Farmer (2016)

64. M.S. Reed, K. Allen, A. Attlee, A.J. Dougill, K.L. Evans, J.O. Kenter, J. Hoy, D. McNab, S.M. Stead, C. Twyman, et al., Global environmental change 43, 92 (2017)

65. Katia Karousakis, Enhancing the effectiveness of payments for ecosystem services (pes) Tech. rep., Environment Directorate, Organisation for Economic Cooperation and Development (OECD), France (2012)

66. Department for Environment, Food and Rural Affairs, Defras payments for ecosystem services pilot projects 2012-15. Tech. rep., UK Government (2016) 